\title{
Review \\ Performance-Based Analysis in Evaluation of Safety in Car Parks under Electric Vehicle Fire Conditions
}

\author{
Dorota Brzezinska *(D) and Paul Bryant \\ Faculty of Process and Environmental Engineering, Lodz University of Technology, Stefana Zeromskiego 116, \\ 90-924 Lodz, Poland; paul.bryant@dokt.p.lodz.pl \\ * Correspondence: dorota.brzezinska@p.lodz.pl; Tel.: +48-603-637-633
}

Citation: Brzezinska, D.; Bryant, P.

Performance-Based Analysis in

Evaluation of Safety in Car Parks under Electric Vehicle Fire

Conditions. Energies 2022, 15, 649.

https://doi.org/10.3390/en15020649

Academic Editor: Florin Mariasiu

Received: 20 December 2021

Accepted: 11 January 2022

Published: 17 January 2022

Publisher's Note: MDPI stays neutral with regard to jurisdictional claims in published maps and institutional affiliations.

Copyright: () 2022 by the authors Licensee MDPI, Basel, Switzerland. This article is an open access article distributed under the terms and conditions of the Creative Commons Attribution (CC BY) license (https:// creativecommons.org/licenses/by/ $4.0 /)$.

\begin{abstract}
Even though electric vehicles (EV) were invented over a century ago, their popularity has grown significantly within the last 10 years due to the development of Li-ion battery technology. This evolution created an increase in the fire risk and hazards associated with this type of high-energy battery. This review focuses on lessons learned from electric vehicle fires and fire risk mitigation measures for passenger road vehicles partially or fully powered by $\mathrm{Li}$-ion batteries. The paper presents EV fire risks, as well as historical car fires, published large-scale fire tests, and some proposed fire protection strategies in the aspect of electromobility safety for the future. Technical solutions for EV fire hazard mitigation are discussed, and methods of performance-based analysis and simulations for fire safety in car park evaluation are demonstrated. The Fire Dynamic Simulator (FDS) was used for the CFD simulations for the prediction of smoke dispersion and temperature distribution during an EV fire. The presented case study demonstrates how fire simulations could predict conditions for the safe evacuation of people and Fire Brigade intervention conditions in the case of an EV fire in a car park.
\end{abstract}

Keywords: li-ion battery; electromobility; hybrid and electric vehicles; electric vehicle fire; battery fire; heat release rate

\section{Introduction}

Hybrid and electric vehicles (EVs) rely on electric power to drive. This review is focused on passenger road vehicles that are partially or fully powered by Li-ion batteries. It also presents how the performance-based fire safety analysis could be used for underground car park safety in the case of EV fires.

EVs are becoming increasingly popular and are not only a symbol of clean transportation, but they also promise excellent technical performance [1,2]. However, compared to conventionally-fueled cars, which still maintain good sales, electric vehicles raise doubts regarding fire safety $[3,4]$. The doubts may be due to EV fire incidents that have happened in previous years (see Section 1.2). It was proven that most of those fire accidents were caused by the thermal runaway of Li-ion batteries, their self-ignition in parked vehicles or while driving, and fires after traffic accidents [5]. Based on the above, it could be concluded that, as a result of the increased popularity of EVs, the probability of fire incidents will also increase.

The literature shows that batteries are not only the first ignited component [6-9]. They also pose the major fuel to feed the vehicle fire, similar to gasoline or diesel fuels in conventional cars. The mechanisms of battery thermal runaway and its fire phenomenon have been reviewed in [9] and are described in Section 1.3. It appears that the most relevant battery fire dynamics are battery material and its chemistry [9].

Fire is one of the many risks that impact vehicles. When considering both battery electric vehicle (BEV) and plug-in hybrid electric vehicle (PHEV) fire incidents, the risk and hazard may be found with the battery cell and power system and may be determined 
by the size and capacity of the battery pack [7]. It could be concluded that the greater the number of batteries installed, the greater the amount of energy will be produced, thus increasing the fire risk $[10,11]$.

Li-ion batteries have become the most common power source for EVs, with increased concerns for passenger safety due to the increasing understanding of LIB hazard issues [12]. It depends on the scale of deployment and energy density of the battery pack. The element lithium itself has questions of safety attributed to it [13]. When a Li-ion battery is physically impacted, it can break, ejecting sparks, gases that are flammable, and toxic combustion products $[14,15]$. These can be further ignited and lead to burning, flames, and/or a gas explosion [16].

A typical battery system, on its own, may have a low probability of self-ignition [17]. However, it is susceptible to external actions, which may be thermal, mechanical, or electrical, possibly because of adverse operating conditions or collisions [18]. Moreover, the low ceilings inside a car park can contribute to fire spread and impede rescue operations. Additionally, as the total number of EVs increases each year, public car parks have decided to install EV charging stations, introducing a new risk for car park fires. Because of this, some have suggested banning charging in parking infrastructures or reducing the number and density of parked vehicles [19].

\subsection{The Electric Vehicle Market Expansion}

The EV was invented in the 19th century [1]. The first efficiently functioning electric car was created in 1882 (batteries used to power the tricycle weighed about $45 \mathrm{~kg}$ ). It is worth adding that electric vehicles competed then with steam vehicles [20]. In the early part of the 20th century, EVs were in demand because of fuel shortages and environmental issues [2]. However, this changed when fossil fuels became cheaper [21]. Nowadays, the reduction in such fuel resources, the increasing market demand, and global warming phenomena have motivated the industry to turn back to EV solutions.

McKinsey's Electric Vehicle Index has suggested that EV sales have been growing significantly every year since 2010 [22]. In 2018, EV ownership was in excess of 5.1 million vehicles. This was an increase of 2 million vehicles from the previous year. China is now regarded as the world's biggest electric car market. Europe and the United States are also major purchasers. Figure 1 shows the global electric car sales and market share from 2013 to 2018. Future trends in the popularity of EVs suggest a dynamic market. $\mathrm{EV}$ vehicle development is strongly based on the stimulation of government policies and technological advances, as well as proactive participation of the private sector, with substantial investment in this sector (Figure 2) [23].

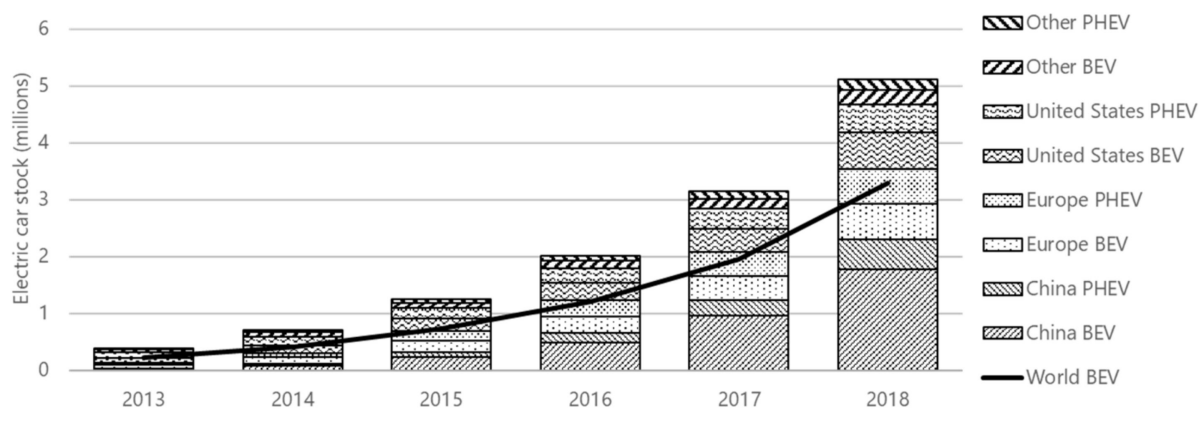

Figure 1. Global electric car sales and market share from 2013 to 2018 (BEVs = battery electric vehicles; PHEVs = plug-in hybrid electric vehicles) [23]. 


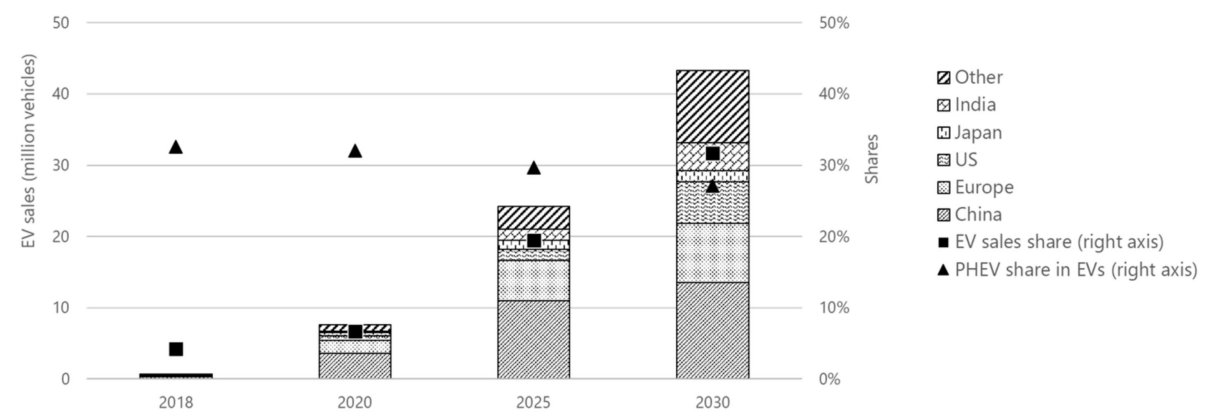

Figure 2. Global future trends of EV popularization for road EVs [23].

\subsection{Performance-Based Fire Engineering}

The Society of Fire Protection Engineers (SFPE) from the United States [24] defines performance-based design as an engineering approach to establish fire safety goals and objectives, to analyze fire scenarios, and to quantitatively assess design alternatives against fire safety goals and objectives. Performance-based designing uses engineering tools, methodologies, and performance criteria.

The concepts behind a performance-based approach were introduced in the 1970s. They allow greater flexibility in the design and application of fire safety and protection systems. After the 1990s, standards were introduced to provide guidance based on a performance-based approach. The key concepts were developed by BSI when, in 2001, British Standard BS 7974 [25] was published. As well as providing a framework for an engineering approach to the achievement of required fire safety in buildings, it also provided a "rational methodology for the design of buildings". The standard was created for designing new buildings and the appraisal of existing buildings. The key benefits reached by the British Standard were that it provided:

- The designer with a uniform approach to fire safety design;

- The safety levels for different designs to be comparable;

- Basis for selection of the most appropriate fire protection systems;

- Opportunities for innovative forms of designing;

- Background on the management methods of fire safety for a building.

The main standard is supported by several guidance documents published as "Public Documents" or PDs. These documents were designed to provide fire safety engineers with additional information to allow them to formulate effective and relevant performancebased fire strategies. Each PD, also referred to as a sub-system, covers a specific area of consideration:

- Fire growth within the enclosure of origin;

- Smoke and toxic gas distribution within and beyond the enclosure of origin;

- Structural response to fire and its spread beyond the enclosure of origin;

- Detection of fire and activation of fire protection systems;

- Fire and rescue service intervention;

- Occupant evacuation conditions;

- Probabilistic risk assessment;

- Property protection, business and mission continuity, and resilience.

\subsection{The Article Structure}

The main goal of the article was to present actual tendencies in EV market growth and historical electric and hybrid vehicle fire accidents. Lessons learned from them suggest that the fire hazard in car parks is strongly increasing. Technical solutions for this hazard mitigation are discussed, and performance-based analysis and simulations of electric vehicle fires for fire safety in car park evaluation are demonstrated. Fire Dynamic Simulator (FDS) 
was used for the CFD simulations for the prediction of smoke dispersion and temperature distribution during an EV fire. The realized analysis steps are presented in Figure 3.

\begin{tabular}{|c|c|c|c|c|c|}
\hline $\begin{array}{c}\text { Lessons learned } \\
\text { from historical } \\
\text { EV fire accidents } \\
\text { fire tests }\end{array}$ & $\begin{array}{c}\text { Technical solu- } \\
\text { tions for EV fires } \\
\text { hazards mitiga- } \\
\text { tion }\end{array}$ & $\begin{array}{c}\text { Methods of per- } \\
\text { formance-based } \\
\text { analysis and } \\
\text { simulations }\end{array}$
\end{tabular}$\quad$\begin{tabular}{c}
$\begin{array}{c}\text { Case study - full- } \\
\text { scale CFD analysis } \\
\text { of the EV fire in a } \\
\text { car park }\end{array}$ \\
\cline { 3 - 5 }
\end{tabular}

Figure 3. Realized analysis steps.

\section{Historical Electric and Hybrid Vehicle Fire Accidents and Lessons Learned}

A review of historical electric and hybrid vehicle fire accidents shows how serious a problem this could be. The following list shows a selection of accidental EV fires from 2008 to 2019. Because the number of EV fire incidents in car parks is relatively small, the cases presented below demonstrates various types of fire events in these cars. The intention was to present in which situations an EV fire could appear. In general, similar situations could happen in a car park, and stakeholders should be aware of this risk.

- 7 June 2008: A Toyota Prius caught fire due to spontaneous ignition while in transit. This vehicle was converted to a PHEV. The main reason could be an improper assembly of bolted joints with electrical lugs inside the battery pack, which triggered the overheating and thermal runaway of the battery cell [26];

- June 2011: A Chevrolet Volt spontaneously caught fire almost three weeks after the crash-test exercise [27,28];

- 18 October 2011: In Merida, Mexico, a Tesla Model S caught fire at high-speed driving through a roundabout and hit a wall and a tree [29,30];

- May 2012: A Nissan GTR crashed and caught fire. The fire was caused by electric arcs created by the short-circuiting of high voltage lines, which ignited the vehicle's combustibles (interior materials and around $75 \%$ of the power batteries) [31];

- 29 October 2012: After Hurricane Sandy flooding, a Toyota Prius Plug-in Hybrid and 16 Fisker Karmas caught fire while being parked in a marine. The fire was caused by saltwater expansion into the electrical system, its corrosion, and finally-a short circuit in the unit [32];

- 18 March 2013: A Mitsubishi i-MiEV caught fire at the Mizushima battery pack assembly while being charged [33,34];

- 1 October 2013: A Tesla Model S caught fire after the vehicle hit debris while being driven on a highway [35]. Flames began coming out both of the fronts at the end of the car. Extinguishing the fire with water obtained from outside of the car was unsuccessful because the fire reignited underneath the vehicle. Water given directly to the burning battery extinguished it finally [36];

- 6 November 2013: A Tesla Model S being driven in Murfreesboro, Tennessee, caught fire after it struck a tow hitch on the roadway that caused damaged beneath the vehicle [37];

- February 2014: In Toronto, Canada, a Tesla Model S caught fire while parked in a garage, but it was not charged [38];

- 1 January 2016 in Norway: A Tesla Model S caught fire while being charged by a Tesla Supercharger [39,40]. The fire grew up slowly, and the owner managed to unplug the car. Tesla suggested a short circuit in the vehicle's distribution box as the direct reason for the fire [41,42]; 
- 15 August 2016 in France: A Tesla Model S 90D caught fire during a promotional test drive. The vehicle started burning spontaneously and was destroyed within 5 min. Tesla suggested a "bolted electrical connection" that was "improperly tightened" under the production process, causing the fire $[43,44]$;

- 25 August 2017 in California: Tesla Model X lost control over an embankment and struck a garage, starting a fire that completely damaged the car [45];

- 18 October 2017 in Austria: A Tesla Model S crashed on a concrete barrier at a motorway, which initiated the fire in the battery at the front of the vehicle [46]. The fire was described as extremely severe with a lot of toxic gas production;

- 7 December 2017 in Germany: A VW e-Golf caught fire in a high-voltage battery space; after initial cooling, the firefighters moved the vehicle into a water container [47];

- January 2018: A driving Kia Optima Hybrid spontaneously caught fire, and the whole car started to burn just $30 \mathrm{~s}$ after it started. The causes were electrical in nature but not determined in detail. [48];

- 16 March 2018 in Thailand: A Panamera E-Hybrid burst into flames while being plugged into a household outlet for charging [49];

- August 31, 2018: A Lifan 650 ignited and was completely lost as the fire could not be extinguished in time. The fire initiated spontaneously under the car, in the battery space. During the fire, several small explosions and significant emissions of toxic black smoke were noticed [50];

- 16 March 2018 in Thailand: A Porsche Panamera caught fire and exploded while its battery was being charged. The reason was an improper installation and working of the charging system [51];

- 8 May 2018: A Tesla Model S hit a wall, causing the battery pack to ignite. The battery reignited twice, requiring it to be extinguished three times in total [52];

- 10 May 2018 in Switzerland: A Tesla Model S caught fire after the vehicle hit the guard-rail on a highway [53,54];

- $\quad 16$ June 2018 in California: A Tesla Model S started to smoke while being parked in the street and flames started shooting out from under it [55]. Firefighters were able to extinguish the fire effectively, and the cabin was left unaffected [56,57];

- 8 February 2019 in Pennsylvania: A Tesla Model S caught on fire being parked in a garage. The same car caught on fire again two months later (on April 8th), while it was under investigation [58];

- 24 February 2019 in Florida: A Tesla Model S burst into flames just after it crashed into a tree, was effectively extinguished, and repeatedly caught fire after being brought to the car park used by police [59,60];

- 24 February 2019 in Canada: A Tesla Model X was completely burned in the middle of a frozen lake; during the fire, numerous small explosions were noticed, and firefighters arrived about $30 \mathrm{~min}$ after the fire began, which appeared to be too late [61];

- 21 April 2019 in China: A Tesla Model S caught on fire and exploded in an underground car park; in total, five cars were damaged by the fire [62]; May 2019: An Outlander caught fire after immersion in saltwater [63];

- 4 May 2019: A Tesla Model S spontaneously caught on fire while not plugged in, with smoke observed near the rear right tire [64]; 13 May 2019: A Tesla Model S in Hong Kong caught on fire while parked [65];

- 1 June 2019 in Belgium: A Tesla Model S burned down while supercharging [66];

- 10 August 2019 in Russia: A Tesla Model 3 hit a truck on a high-speed road and subsequently burned down [67];

- 12 November 2019 in England: A Tesla Model X from 2017 burst into flames while charging [68]. The fire ignition was confirmed in the battery pack, and it was caused by an impact on one of the battery pack modules [35];

- 26 July 2019 in Canada: A Kona Electric caught on fire while being parked in a residential garage in Montreal. The car was not plugged in. The fire triggered an explosion and caused damage to the attached structure [69]; 
- 28 July 2019 in South Korea: A Kona Electric caught fire while charging [70];

- 13 August 2019 in South Korea: A Kona Electric burst into flames while being charged in an underground car park. The vehicle was completely destroyed [71];

- 1 May 2019 in Portugal: A Porsche Panamera E-Hybrid caught fire after hitting a pillar of a bridge [72];

- 16 February 2020 in Florida: A Porsche Taycan completely burned while parked in a residential garage [73].

\section{Lessons from Historical Accidents}

As detailed in the previous section, EV fires have been widely reported in recent years. Note that the total number of EV fires is much smaller than traditionally-fueled fires [3,74]. When a fire incident involves EVs, an investigation often shows that the battery was the primary cause. However, the battery fire can be attributed to many other factors, which may include charging system failures, cable overload, or arson $[75,76]$. The research shows that when a battery fails, it can create several different outcomes, such as venting, fire, or even internal battery explosions. Additionally, if the gas vented from the battery accumulates in a confined space of the vehicle body, it could also lead to an explosion outside of the battery box. This type of external explosion is usually not addressed by battery testing. Thus, it is less well recognized than internal battery explosions [77]. EV fire scenarios are still being updated. Instances can be categorized as one or more of the following:

- The EV catches fire while stationary (self-ignition). This may be caused by extreme weather conditions (low/high temperatures and high humidity, saltwater destruction) or internal cell failure.

- The EV catches fire while being charged. This failure may be due to battery failure due to overcharging and/or faulty or insecure charging stations and/or cables.

- The EV catches fire as a result of a collision or other types of damage.

- EV batteries are also a subject of thermal abuse and reignition after fire extinguishment [19].

The listed EV fires (Section 1.2) show that thermal runaway (a dramatically increasing battery temperature) is the most common cause of fire and can be due to battery failure. It is a widely observed phenomenon with overheating incidents that exothermic chain reactions take place [78-80]. Battery thermal runaway is often accompanied by smoke production, sparking, and flames [81]. Additionally, if the released gas accumulates in an enclosed area and is mixed with surrounding oxygen, a gas explosion may occur $[7,80]$. As mentioned before, all the presented fire situations could happen in enclosed carparks, where their consequences would be much more severe than outside.

\section{Controls on EV Production and Approvals}

EV batteries, before they can be sold, are required to pass standard tests (e.g., in accordance with ISO 12405-3, ISO 6469-1, UN 38.3, UN R100, SAE J2464, SAE J2929, IEC 62133, IEC 626602, IEC 62660-3, GB/T 31485). Requirements differ between countries [82,83], but generally, all EV batteries must pass safety tests that evaluate their failure response [84]. Another goal is set by battery fire tests. In this case, fire growth and development are observed to determine possible consequences in a real fire accident.

\subsection{Standard Tests for EV Batteries}

As highlighted above, the most common battery failure mode is a thermal runaway, which could be triggered after mechanical, thermal, and electrical damage. In such cases, the battery voltage drops because of damage to battery electrodes. Its temperature rises above the heat dissipation rate. The pressure increases because of the reaction among active battery materials, their organic electrolyte evaporation, and flammable gas generation, leading to an accumulation of gases in the battery [85]. The main parameters that are measured during the tests are voltage, current, and temperature [86]. The European 
Council for Automotive Research and Development (EUCAR) provides a classification system (Table 1).

Table 1. EUCAR Hazard Severity Levels [87].

\begin{tabular}{|c|c|c|}
\hline Hazard Level & Description & Classification Criteria and Effect \\
\hline 0 & No effect & No effect. No loss of functionality \\
\hline 1 & $\begin{array}{l}\text { Passive protection } \\
\text { activated }\end{array}$ & No physical damage nor fire hazard. \\
\hline 2 & Defect/damage & No fire hazard, but physical cell damage noticed. \\
\hline 3 & Leakage-mass loss $<50 \%$ & No fire hazard but electrolyte weight loss $<50 \%$ \\
\hline 4 & Venting-mass loss $\geq 50 \%$ & No fire hazard but electrolyte weight loss $\geq 50 \%$ \\
\hline 5 & Fire or flame & $\begin{array}{c}\text { Fire hazard but no rupture or explosion (no } \\
\text { flying parts) }\end{array}$ \\
\hline 6 & Rupture & Fire hazard with flying parts but no explosion \\
\hline 7 & Explosion & $\begin{array}{c}\text { Fire hazard with flying parts and explosion } \\
\text { (i.e., disintegration of the cell) }\end{array}$ \\
\hline
\end{tabular}

\subsection{Real Scale Tests for EV Batteries}

Unfortunately, research into large-scale EV battery testing is still inconclusive. The literature warns against misinterpretation of the data of small-scale battery fires in an attempt to evaluate the hazards of large-scale EV fires $[19,88,89]$.

For fire engineering evaluation purposes, the heat release rate (HRR) or the total heat release from fire is the standard measurement of fire size and is the most important parameter of the EV fire hazard assessment [78], for use when assessing car park fire safety system designs [90-93]. The HRR can be taken as:

$$
\mathrm{HRR}=\dot{\mathrm{m}} \Delta \mathrm{H}_{\mathrm{e}}=\mathrm{A}_{\mathrm{f}} \dot{\mathrm{m}}^{\prime \prime} \mathrm{y} \Delta \mathrm{H}_{\mathrm{c}}
$$

where $\dot{m}$ is the burning rate $\left[\mathrm{kg} / \mathrm{s}\right.$ ] determined by the mass-loss rate from testing [94]; $\Delta \mathrm{H}_{\mathrm{e}}$ is the heat of combustion [MJ $/ \mathrm{kg}] ; \mathrm{A}_{\mathrm{f}}$ is the floor/surface area of fuel or fire $\left[\mathrm{m}^{2}\right]$, which is the floor of the EV; $\dot{\mathrm{m}}^{\prime \prime}$ is the burning flux $\left[\mathrm{kg} / \mathrm{m}^{2}\right.$-s]; is the combustion efficiency, which depends on the oxygen supply; and $\Delta \mathrm{H}_{\mathrm{c}}$ is the heat of combustion for EV batteries, which varies with the type and SOC of LIB.

The exact EV battery fire size is not conclusive. For example, the Tesla Model $S$ battery of $2250 \mathrm{~kg}$ is five times greater than that of a battery cell (45 $\mathrm{g}$ for a 18,650 cell), and the HRR of fire is increased three times. The HRR can range from several $\mathrm{kW}$ for a battery cell [10] to several hundred $\mathrm{kW}$ for a single EV battery pack [88] and several MWs for a full-scale EV fire $[19,89]$.

The energy of an EV fire can also be assessed by using the average heat flux ( $\left.q^{\prime \prime}\right)$ of the battery pack and its area. For the calculation, the SOC can be taken as $100 \%$, which represents the worst-case fire scenario [95]. Using the example of an EV powered by Lithium Titanate (LTO) batteries, the average heat flux ( $\left.\mathrm{q}^{\prime \prime}\right)$ is approximately $2.3 \mathrm{MW} / \mathrm{m}^{2}$ in a fully charged stage [96]. Considering the floor area of the battery $\mathrm{A}_{\mathrm{EV}} \approx 3 \mathrm{~m}^{2}$, the average fire HRR of this kind of EV can be estimated as 7 MW (1).

$$
\mathrm{HRR}=\mathrm{A}_{\mathrm{EV}} \mathrm{q}^{\prime \prime}=3 \mathrm{~m}^{2} \times 2.3 \mathrm{MW} / \mathrm{m}^{2} \approx 7 \mathrm{MW}
$$

This calculated HRR could also be used to evaluate the necessary amount of water or other fire-suppression agents to extinguish the EV fire.

\subsection{Fire Suppression and Mitigation Strategies}

Batteries typically must accumulate energy to initiate the thermal runaway. This makes EVs distinct from petrol vehicles, which reach the fuel flammability limit much faster. However, once the battery starts to burn. It is very difficult to extinguish the resulting 
fire. In the case of battery failure, there may not be an apparent sign of the fire phenomenon at the onset, which may lead to delays in extinguishing it [97].

It is widely stated that LIB fires cannot be easily extinguished and require large amounts of suppressants. Even then, there is the potential for re-ignition [85]. Such reignition can occur at random. Full-scale testing of extinguishing EV battery fires revealed the amount of water necessary to extinguish such a fire, which can vary from 2500 to 6000 $\mathrm{L}$ and may exceed even the volume of water held by one fire truck [98]. Furthermore, the suggested flow rate is very high at $200 \mathrm{~L} / \mathrm{min}$ for extinguishing and cooling [99].

In general, an LIB fire should be cooled at its source. Access to the place of fire can be difficult because the battery pack is most often located in places that are difficult to access [77]. At the same time, the effectiveness of suppression agents other than water is often questioned. Some other means of controlling fire, such as the use of inert or chemical agents, may extinguish the flames, but there is the possibility of a build-up of flammable gas and explosion [100]. It was found that if only carbon dioxide or other neutral chemicals are used to suppress the battery fire, the fire can be controlled, but it cannot cool down the battery or prevent re-ignition. In conclusion, only water offers a satisfactory effect in cooling and gaining control over LIB fires. Despite potential negative effects, such as short circuits or toxic runoff, water appears to be most effective as an extinguishing method [101].

Colella performed large-scale fire tests using water mist systems. The results concluded that the water mist could be very effective in fire temperature control, and it is believed that this method will be the subject of subsequent research [88]. Without fire suppression, the continuous ignition of battery cells was observed with externally visible flames [102].

Larger EVs may incorporate internal fire suppression systems. In buses, such systems are required in at least 63 countries through UNECE Reg. No. 107 [103], but they are normally not specified for LIBs. This could be because of the limited capacity of fire extinguishers onboard and the difficulty in EV fire suppression.

Other solutions for EV fire risk mitigation may be provided by fire industry associations. The National Fire Protection Association (NFPA) has developed standards to address the growth in EV charging stations. One of them is the NFPA guide [104,105], which recommends storage of a vehicle containing a burned or damaged LIB at a minimum distance of $15 \mathrm{~m}$ from structures, combustible materials, or other vehicles, and using infrared camera monitoring until the battery is discharged. The Society of Automotive Engineers in SAE J2293 and J1772 provide another key design requirement to ensure interoperability with EVs [106,107], providing the following steps for holding damaged EVs:

- The EV should not be kept in enclosures until it has been inspected as per SAE J2990 procedures.

- The EV should be located away from combustible materials, structures, and other vehicles by a distance of at least $15 \mathrm{~m}$. This also applies to vehicles enclosed by walls made of non-combustible material (from 3 of 4 sides), where the open side must be at least $15 \mathrm{~m}$.

- The vehicle's windows/doors should be kept open to allow for ventilation of potentially dangerous gases.

- The EV should not be exposed to rain or other precipitation if the LIB is ruptured.

Very useful recommendations concerning EVs' handling can also be found at a knowledge platform and training center for the automotive industry in the Benelux areaEDUCAM [107]. They define specific cases when a vehicle may be kept at a regular parking space and when it must be moved to specific locations. The conditions are listed below.

1. The vehicle may remain in a regular parking space waiting for repair:

- The vehicle presents ideal working condition and no-fault code history for powertrain and BMS are reported, and the case is undamaged;

- The vehicle presents a damaged case, but no fault code history for powertrain and BMS are reported, but structural integrity stays intact; 
- The vehicle presents a fault-warning fault codes for powertrain and/or BMS are reported, but the case is undamaged;

- The vehicle presents a fault-warning fault codes for powertrain and/or BMS are reported, and the case is damaged, but structural integrity stays intact.

2. The vehicle must be moved to a secured location before work:

- The vehicle presents a fault-warning fault codes for powertrain and/or BMS are reported, and structural integrity is affected;

- The vehicle presents signs of water damage (due to ingress of sault or rainwater).

EDUCAM [108] also provides guidance on measures and procedures to be followed in securing EVs, based upon identified hazards. The first step is to warn personnel about the hazard. The other categories relate to elements that can cause a fire or chemical hazard:

- Following the emergency response guide of the vehicle recommendations or if it is not available: disconnect $12-\mathrm{V}$ battery and keep a safety distance of $10 \mathrm{~m}$ to all nearby objects for at least $48 \mathrm{~h}$ and $2 \mathrm{~m}$ after $48 \mathrm{~h}$;

- Do not store EVs or high-voltage batteries inside buildings;

- Collect leaking electrolyte by using an appropriate collection tray.

\section{CFD Simulations for Car Park Fire Safety Evaluation}

\subsection{Fire Dynamics Simulator}

The most widely used field model for fire safety analysis is known as the Fire Dynamics Simulator (FDS) [109] and is produced by the National Institute of Standards and Technology (NIST) in the United States.

When assessing life safety parameters, it is necessary to adopt established tenability limits that would ensure a specific safety level for people during a fire. In Poland, such criteria were regulated in 2011 based on British Standard requirements from PD 7974-6 [110]. According to them, critical parameters (tenability limits) on evacuation routes are considered:

- Smoke at a head height $\leq 1.8 \mathrm{~m}$ from the floor, limiting the visibility of building features and luminescent evacuation signage to not more than $10 \mathrm{~m}$; and

- Air temperature at a head height $\leq 1.8 \mathrm{~m}$ from the floor not exceeding $60^{\circ} \mathrm{C}$.

The FDS program enables three-dimensional simulations of fire growth and smoke spread based upon the CFD calculations using the Navier Stokes equations for fire-driven fluid flows, with emphasis on smoke and heat transport. The program is aimed at solving performance-based problems in fire protection engineering while, at the same time, allowing the study of fundamental fire dynamics and combustion processes [111].

To describe the turbulence phenomenon, the FDS program utilizes large eddy simulation (LES), the process of turbulent mixing of gaseous fuel and combustion products with combustion ambient air. This simulates most fires and determines the fuel combustion rate and the smoke and hot gases spread rate. The basic assumption when utilizing LES is that most eddies arising in the process of gas mixing are sufficiently large to be computed with satisfactory approximation accuracy by means of the fluid dynamics equations. All small eddies are computed with high approximation accuracy or are neglected [111,112].

The following models for the description of process fluid mechanics were employed in the FDS program:

- Hydrodynamic model;

- Combustion model;

- Thermal radiation model;

- Model of thermal penetration through barriers;

- Pyrolysis model.

\subsection{Boundary and Initial Conditions for CFD Simulations}

For the CFD simulations, it is necessary to assume some initial conditions of external and internal air parameters. It depends on the local situation, but on the basis of the 
author's experience, usually, it is assumed that the air temperature is $20{ }^{\circ} \mathrm{C}$, ambient pressure is $1013 \mathrm{hPa}$, and relative air humidity is $40 \%$. Building partitions are assumed to be made of concrete with a density of $2100 \mathrm{~kg} / \mathrm{m}^{3}$, a thermal conductivity of $1.0 \mathrm{~W} / \mathrm{mK}$, and a specific heat of $0.88 \mathrm{~kJ} / \mathrm{kgK}$. A mixture of polystyrene and wood was taken as the combustion material, representing combustible materials potentially present in the room for which simulations were carried out. The SOOT_YIELD coefficient, i.e., the mass fraction of the fuel that is converted into soot, could be $0.07 \mathrm{~kg} / \mathrm{kg}$, and the heat of combustion could be $20,000 \mathrm{~kJ} / \mathrm{kg}$. A computational grid with a density of $0.3 \mathrm{~m}$ in the simulation's $\mathrm{X}, \mathrm{Y}$, and $\mathrm{Z}$ directions is used. All the above assumptions are based on the long author's practice of simulations; however, they should always be carefully analyzed, relative to the individual conditions of the project.

Fire spread scenario; NFPA 204 [113], recommends that the analysis of computational fire development is in accordance with the standard fire development curve given described as a model:

$$
\mathrm{Q}=\alpha \mathrm{t}^{2}
$$

where:

$\mathrm{Q}$-heat release rate $[\mathrm{kW}]$,

A-fire growth coefficient $\left[\mathrm{kW} / \mathrm{s}^{2}\right]$,

T-time [s].

Fire scenario analysis considered the appropriate fire size of fire $7 \mathrm{MW}$ calculated earlier and firefighting brigade arrival after $480 \mathrm{~s}$ from the start of the fire, as shown in Figure 4.

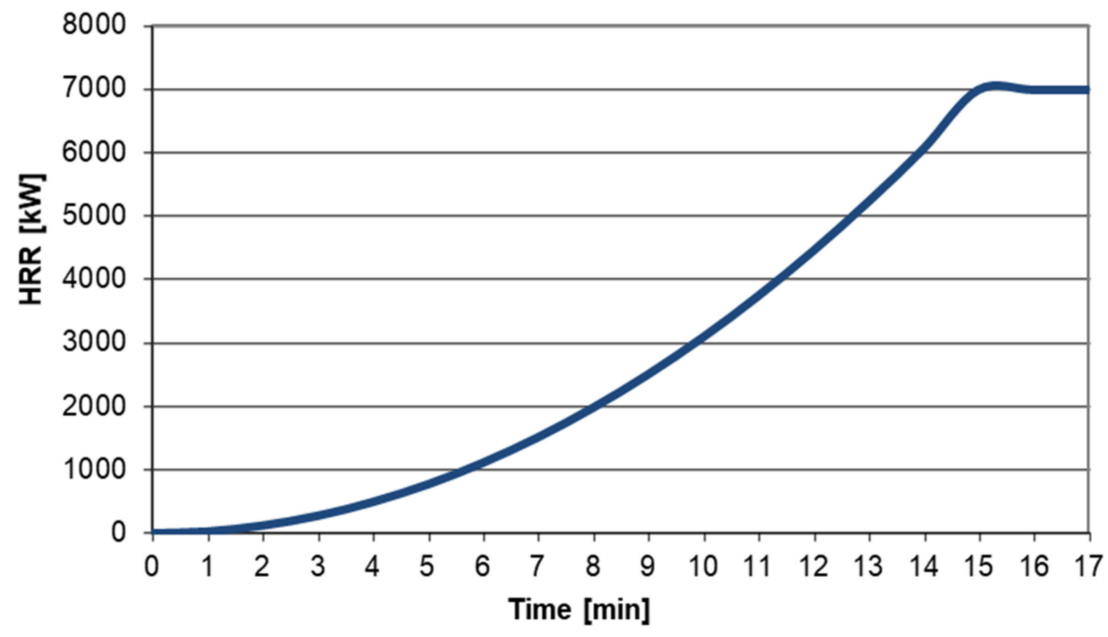

Figure 4. HRR curve of the fire.

\subsection{The Exemplar CFD Simulation}

Below, an exemplar simulation of the EV fire in a car park is demonstrated. The car park's space was chosen randomly, and the intention was to show how such a performancebased approach could be conducted rather than to show its general results. The car park space is presented in Figure 5. The fire was assumed at an electrical car park place in the central part of the car park. The scheme also presents evacuation exits and the main gate to the car park, which constituted, at the same time, the opening for the fresh air supply. The car park was also equipped with a smoke control system with ducts installed below the ceiling. 


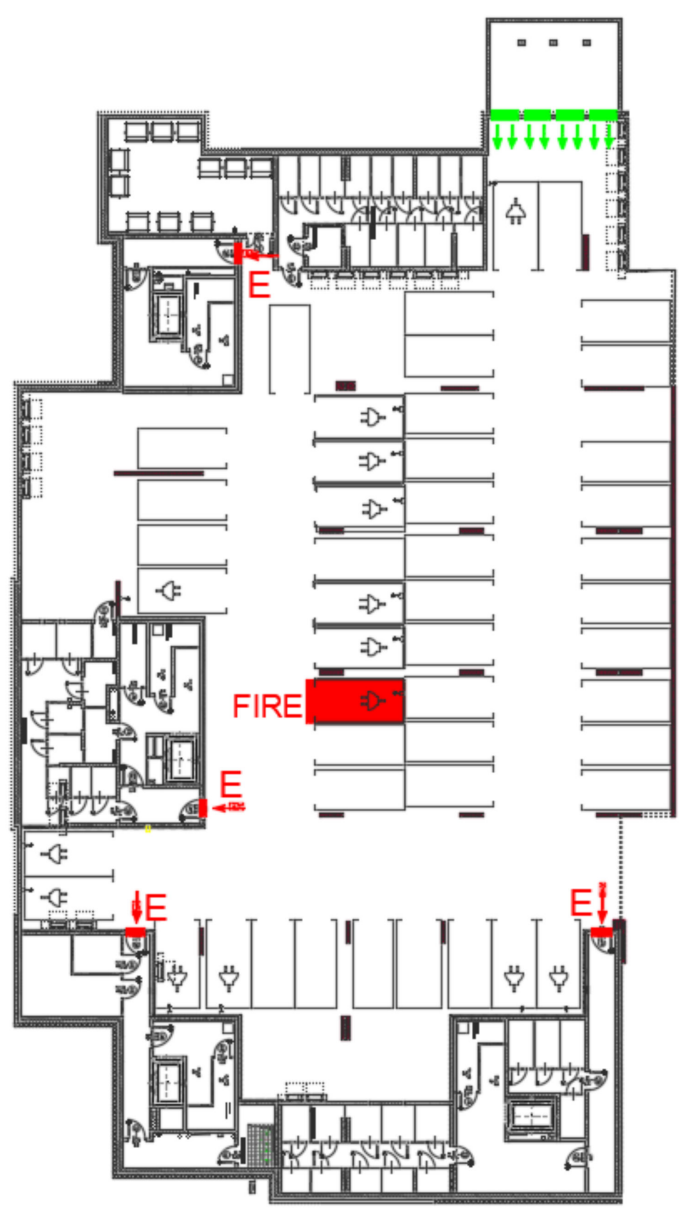

Figure 5. Scheme of the car park.

Temperature distribution and visibility range at an altitude of up to $1.8 \mathrm{~m}$ from the floor were modeled using the FDS software. According to the standard PD 7974-6 [110], the limits of the values of the individual parameters should be:

- The maximum tenable temperature for escape is $60^{\circ} \mathrm{C}$. Note that, to take into account a suitable margin of error for the simulation, the actual temperature requires that the tenable temperature should be reduced to $52^{\circ} \mathrm{C}$;

- $\quad$ The visibility range is taken as $10 \mathrm{~m}$ for non-lit areas and $30 \mathrm{~m}$ for illuminated evacuation signs.

\subsection{CFD Simulation Results}

Figures 6 and 7 provide a graphical presentation of the CFD simulation results over a number of time periods. For the adopted parameters of fire development, on the basis of preliminary analyses, it was assumed that the time of the starting fire alarm in the analyzed object does not exceed $80 \mathrm{~s}$ from the moment the fire occurred (the range of smoke under the ceiling after $80 \mathrm{~s}$ from the start of the fire exceeds the diameter of $20 \mathrm{~m}$, which guarantees the operation of at least two smoke detectors, located in the spacing every $10 \mathrm{~m}$ ). 


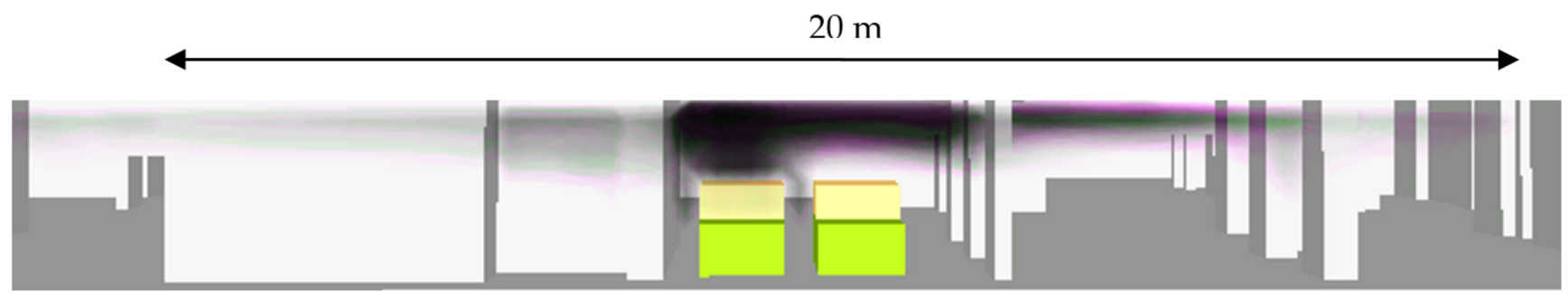

Figure 6. Detection activation—starting fire alarm.

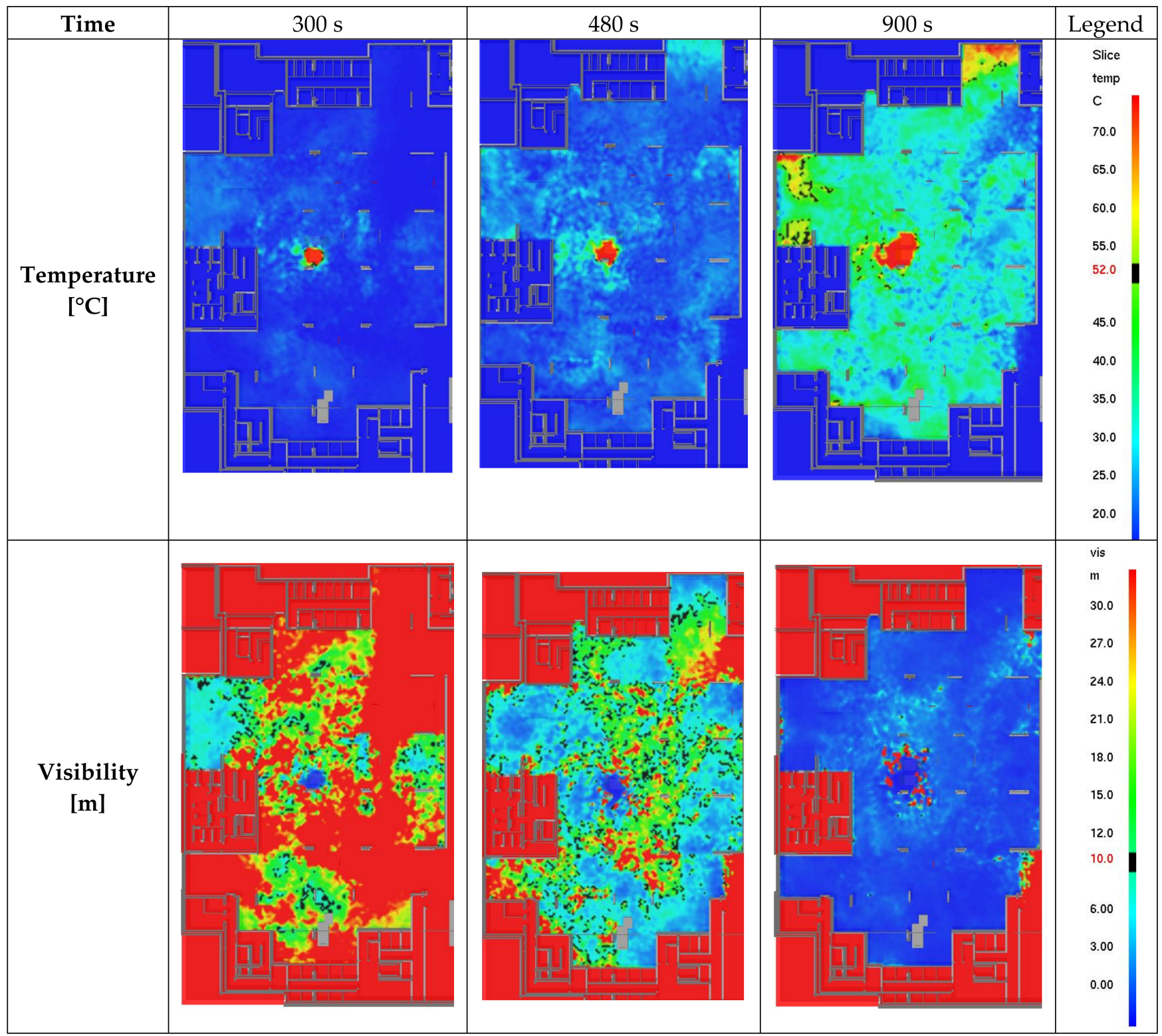

Figure 7. Graphical presentation of the CFD simulation results.

The time of fire detection was used as the time of smoke control activation and was used for the simulations. Based on the boundary conditions described above, the fire simulation was conducted.

In this case, the progression of fire in terms of both obscuration and temperature distribution is considered. The time periods chosen for the analysis are: 
1. $300 \mathrm{~s}$ : this represents the completion of the evacuation from the immediate effects of fire. The visibility range that is of interest;

2. $480 \mathrm{~s}$ : this is the time calculated as when the fire brigade will arrive on site. The fire continues to grow. Note that the visibility range and temperature distribution are of interest at this point;

3. $900 \mathrm{~s}$ : this is the completion of the simulation period; the fire stops growing due to reaching maximum HRR.

It can be seen that, at a head height of $1.8 \mathrm{~m}$, the visibility range falls below the required $10 \mathrm{~m}$ after the calculated evacuation time has been reached in this area. At the time of arrival of the Fire Brigade, the temperature limit value of $60^{\circ} \mathrm{C}$ (adjusted to $52{ }^{\circ} \mathrm{C}$ to allow for a margin of error $15 \%$ ) has not been exceeded. Furthermore, the fire brigade should still be set up for firefighting by $900 \mathrm{~s}$.

The CFD simulations make it possible to assess that electric car fire in a garage would not pose a threat to the people staying in it, and they would have time to evacuate before the occurrence of the boundary conditions of the fire. The simulation results demonstrate that as the fire develops, the temperature in the garage increases, and the visibility decreases. This means that the conditions for evacuating people from the garage are deteriorating. Additionally, the Fire Brigade arrival time temperature does not exceed the tenability limit of $60^{\circ} \mathrm{C}$ and allows them to start extinguishing.

\section{Conclusions}

This paper provides a review of recent battery fires in electric vehicles (EVs), as well as the related fire-safety issues and associated fire-protection strategies. An increased number of EV fire accidents is observed as the market share of EVs as part of all vehicle purchases continues to rise. The lack of full-scale EV fire tests the limits of engineering knowledge of the real EV fire hazard, but the generally accepted heat release rate (HRR) for fire engineering design for car parks should be taken as being around $7 \mathrm{MW}$, and fire growth should be assumed to be much faster compared to conventionally-fueled vehicles.

EV fires are difficult to suppress because of the difficulty of accessing the battery pack located inside of the vehicle body and the potential re-ignition risks. Water is still considered to be the most effective method of suppressing EV fires, although it is required in significant amounts to be successful.

Performance-based analysis and CFD simulations are demonstrated as practical tools for fire safety in car park evaluation. The Fire Dynamic Simulator (FDS) was used for the CFD simulations for the prediction of smoke dispersion and temperature distribution during an EV fire. The simulation results demonstrate that as the fire develops, the temperature in the garage increases, and the visibility decreases. This means that the conditions for evacuating people from the garage are deteriorating. Depending on the purpose of the garage, the expected time of the evacuation of people may vary. Thus, the CFD simulations presented make it possible to assess whether an electric car fire in the garage would not pose a threat to the people staying in it and whether they would have time to evacuate before the occurrence of the boundary conditions of the fire. Similarly, the simulations allow for the evaluation of the Fire Brigade activity conditions.

\section{Limitations and Future Research Work}

Even though performance-based methods have been used for many years, there are still definite gaps in this knowledge and some conflicting findings that often decide the final project results. The most questionable element in this field is the EV fires' potential HRR and its growth rate. These two elements are still discussed. Future research in this field requires especially new fire tests that would show how different the EV's fire could be in comparison to the conventional car fire. The problem is that such tests are very expensive, and a piece of reliable information could not be obtained from a single test, but from a whole series of tests. This means that now the designers have to make performance-based 
assumptions and data from the individual battery tests and calculations of the expected EV HRR, as was presented in the article.

Author Contributions: Conceptualization, D.B.; methodology, D.B.; formal analysis, D.B.; resources, D.B.; data curation, D.B.; writing-original draft preparation, D.B.; writing-review and editing, P.B.; visualization, D.B.; project administration, D.B. All authors have read and agreed to the published version of the manuscript.

Funding: This research received no external funding.

Institutional Review Board Statement: Not applicable.

Informed Consent Statement: Not applicable.

Conflicts of Interest: The authors declare no conflict of interest.

$\begin{array}{ll}\text { Abbreviations } \\ \text { BMS } & \text { Battery management system } \\ \text { BEV } & \text { Battery electric vehicles } \\ \text { CFD } & \text { Computational fluid dynamics } \\ \text { EUCAR } & \text { European Council for Automotive Research and Development } \\ \text { EV } & \text { Electric vehicle } \\ \text { FDS } & \text { Fire Dynamic Simulator } \\ \text { HRR } & \text { Heat release rate [W] } \\ \text { ICEV } & \text { Internal combustion engine vehicle } \\ \text { LIB } & \text { Lithium-ion battery } \\ \text { LTO } & \text { Lithium Titanate } \\ \text { NFPA } & \text { National Fire Protection Association } \\ \text { NIST } & \text { National Institute of Standards and Technology } \\ \text { PHEV } & \text { Plug-in hybrid electric vehicle } \\ \text { PD } & \text { Public Document } \\ \text { SAE } & \text { Society of Automotive Engineers } \\ \text { SOC } & \text { State of charge (\%) } \\ \text { SFPE } & \text { Society of Fire Protection Engineers } \\ \text { UNECE } & \text { United Nations Economic Commission for Europe } \\ \text { Q } & \text { Fire heat release rate [kW] } \\ \text { T } & \text { Time [s] } \\ \text { A } & \text { Fire growth coefficient [kW/ }{ }^{2} \text { ] }\end{array}$

\section{References}

1. Matulka, R. The History of the Electric Car. Department of Energy. 2014. Available online: https://www.energy.gov/articles/ history-electric-car (accessed on 20 October 2018).

2. Anderson, C.D.; Anderson, J. Electric and Hybrid Cars, 2nd ed.; McFarland \&Company: Jefferson, NC, USA, 2010.

3. Boehmer, H.; Klassen, M.; Olenick, S. Modern Vehicle Hazards in Parking Structures and Vehicle Carriers. 2020. Available online: https:/ / www.nfpa.org/News-and-Research/Data-research-and-tools/Building-and-Life-Safety/Modern-VehicleHazards-in-Parking-Garages-Vehicle-Carriers (accessed on 10 May 2021).

4. Bisschop, R.; Willstrand, O.; Rosengren, M. Handling lithium-ion batteries in electric vehicles-preventing and recovering from hazardous events. In Proceedings of the 1st International Symposium on Lithium Battery Fire Safety, Hefei, China, 18-20 July 2019.

5. National Transportation Safety Board. Preliminary Report: Crash and Post-Crash Fire of Electric-Powered Passenger Vehicle; National Transportation Safety Board: Washington, DC, USA, 2018.

6. Wang, Q.; Ping, P.; Zhao, X.; Chu, G.; Sun, J.; Chen, C. Thermal runaway caused fire and explosion of lithium ion battery. J. Power Sources 2012, 208, 210-224. [CrossRef]

7. Wang, Q.; Mao, B.; Stoliarov, S.I.; Sun, J. A review of lithium ion battery failure mechanisms and fire prevention strategies. Prog. Energy Combust. Sci. 2019, 73, 95-131. [CrossRef]

8. Feng, X.; Ouyang, M.; Liu, X.; Lu, L.; Xia, Y.; He, X. Thermal runaway mechanism of lithium ion battery for electric vehicles: A review. Energy Storage Mater. 2018, 10, 246-267. [CrossRef]

9. Ouyang, D.; Chen, M.; Huang, Q.; Weng, J.; Wang, Z.; Wang, J. A review on the thermal hazards of the lithium-ion battery and the corresponding countermeasures. Appl. Sci. 2019, 9, 2483. [CrossRef] 
10. Liu, X.; Wu, Z.; Stoliarov, S.I.; Denlinger, M.; Masias, A.; Snyder, K. Heat release during thermally-induced failure of a lithium ion battery: Impact of cathode composition. Fire Saf. J. 2016, 85, 10-22. [CrossRef]

11. Liu, X.; Stoliarov, S.I.; Denlinger, M.; Masias, A.; Snyder, K. Comprehensive calorimetry of the thermally-induced failure of a lithium ion battery. J. Power Sources 2015, 280, 516-525. [CrossRef]

12. Balakrishnan, P.G.; Ramesh, R.; Prem Kumar, T. Safety mechanisms in lithium-ion batteries. J. Power Sources 2006, 155, 401-414. [CrossRef]

13. Tobishima, S.I.; Yamaki, J.I. A consideration of lithium cell safety. J. Power Sources 1999, 81-82, 882-886. [CrossRef]

14. Evarts, E.C. Lithium batteries: To the limits of lithium. Nature 2015, 526, S93-S95. [CrossRef]

15. Lecocq, A.; Eshetu, G.G.; Grugeon, S.; Martin, N.; Laruelle, S.; Marlair, G. Scenario-based prediction of Li-ion batteries fire-induced toxicity. J. Power Sources 2016, 316, 197-206. [CrossRef]

16. Gough, N. Sony Warns Some New Laptop Batteries May Catch Fire. The New York Times, 12 April 2014. Available online: https:/ / www.nytimes.com/2014/04/12/technology/sony-warns-some-new-laptop-batteries-may-catch-fire.html(accessed on 20 March 2019).

17. Liu, Y.; Sun, P.; Niu, H.; Huang, X.; Rein, G. Propensity to self-heating ignition of open-circuit pouch Lithium-ion battery pile on a hot boundary. Fire Saf. J. 2021, 120, 103081. [CrossRef]

18. He, X.; Restuccia, F.; Zhang, Y.; Hu, Z.; Huang, X.; Fang, J.; Rein, G. Experimental study of self-heating ignition of lithium-ion batteries during storage and transport: Effect of the number of cells. Fire Technol. 2020, 56, 2649-2669. [CrossRef]

19. Sun, P.; Huang, X.; Bisschop, R.; Niu, H. A Review of Battery Fires in Electric Vehicles. Fire Technol. 2020, 56, 1361-1410. [CrossRef]

20. Business Insider Polska. Available online: https://businessinsider.com.pl/motoryzacja/pierwszy-samochod-elektryczny-naswiecie-historia-motoryzacji/2jxm5w0 (accessed on 11 November 2021).

21. Grauers, A.; Sarasini, S.; Karlstrom, M.; Industriteknik, C. Why electromobility and what is it? In Systems Perspectives on Electromobility; Sande'n, B., Ed.; Chalmers University of Technology: Goteborg, Sweden, 2013.

22. Hertzke, P.; Müller, N.; Schenk, S.; Wu, T. The Global Electric-Vehicle Market Is Amped up and on the Rise; McKinsey Center for Future Mobility, McKinsey \& Company: Atlanta, GA, USA, 2018.

23. Global EV Outlook. Scaling-Up the Transition to Electric Mobility; Energy Technology Policy (ETP) Division of the Directorate of Sustainability, Technology and Outlooks (STO), International Energy Agency: London, UK, 2019.

24. SFPE Website. Society of Fire Protection Engineers. Available online: https://www.sfpe.org/page/about (accessed on 11 August 2020).

25. BS 7974:2019; Application of Fire Safety Engineering Principles to the Design of Buildings. Code of Practice. British Standards Institution: London, UK, 2019.

26. Beauregard, G.P.; Phoenix, A.Z. Report of Investigation: Hybrids Plus Plug in Hybrid Electric Vehicle; National Rural Electric Cooperative Association, Inc.: Phoenix, AZ, USA; US Department of Energy, Idaho National Laboratory by ETEC: Arlington, TX, USA, 2008

27. Jensen, C. Chevy Volt Fire Prompts Federal Investigation Into Lithium-Ion Batteries. The New York Times, 11 November 2011.

28. Green, J.; Welch, D.; Keane, A.G. GM Volt Fire Prompts Probe of Lithium Batteries. Bloomberg, 11 November 2011.

29. Blanco, S. Second Tesla Model S fire caught on video after Mexico crash. Autoblog Green, 9 November 2013.

30. Hyde, J. Second Tesla Model S fire sparked by crash in Mexico. Yahoo Autos, 9 November 2013.

31. Investigation concludes fire in BYD e6 collision caused by electric arcs from short circuit igniting interior materials and part of power battery. Green Car Congress, 13 August 2012.

32. Voelcker, J. Sandy Flood Fire Followup: Fisker Karma Battery Not At Fault. Green Car Reports, 7 November 2012.

33. Tabuchi, H. New Problem for Boeing 787 Battery Maker. The New York Times, 13 April 2013.

34. Mitsubishi Motors Press Release. Mitsubishi reports fire in i-MiEV battery pack, melting in Outlander PHEV pack. Green Car Congress, 13 April 2013.

35. Jensen, C. Tesla Says Car Fire Started in Battery. The New York Times, 5 October 2013.

36. Vlasic, B. Car Fire a Test for High-Flying Tesla. The New York Times, 5 October 2013.

37. Ohnsman, A.; Keane, A.G. Tesla's Third Model S Fire Brings Call for, U.S. Inquiry. Bloomberg, 8 November 2013.

38. Lopez, L. Another Tesla Caught on Fire While Sitting in a Toronto Garage This Month. Business Insider, 16 February 2014.

39. Nygaard, K. Tesla tok fyr og brant helt ut [A Tesla caught fire and burned out completely]. Fædrelandsvennen, 1 January 2016. (In Norwegian)

40. Nygaard, K. Tesla antente under lading og brant opp [A tesla caught fire during charging and burned out]. Aftenposten, 1 January 2016. (In Norwegian)

41. Hattrem, H.; Larsen-Vonstett, Ø. Tesla-brannen: Kortslutning i bilen, men vetikke hvorfor [Tesla fire: Short circuit in the car but do not know why]. VG, 18 March 2016. (In Norwegian)

42. Herron, D. Model S Catches Fire in Norway at Supercharger, Charging System Seemingly at Fault, The Long Tail Pipe. Available online: https:/ /longtailpipe.com/2016/01/01/model-s-catches-fire-in-norway-at-supercharger-charging-system-seeminglyat-fault/ (accessed on 18 March 2019).

43. Lambert, F. Tesla says Model S fire in France was due to 'electrical connection improperly tightened' by a human instead of robots. Electrek, 20 June 2018.

44. Thompson, C. A Tesla Model S burst into flames during a test drive in France. Businessinsider, 20 June 2018. 
45. Mendoza, A. Tesla slams into Lake Forest garage, severely damaging it and sparking a fire. Orange County Register, 8 June 2018.

46. Lambert, F. Tesla Model S fire vs 35 firefighters-Watch impressive operation after a high-speed crash. Electrek, 18 October 2017. Available online: https:/ / electrek.co/2017/10/18/tesla-model-s-fire-high-speed-crash-video-impressive-operation/(accessed on 20 March 2019).

47. Feuerwehr löscht brennenden E-Golf [firefighters extinguish burning E-Golf]. Wolfsburger Allgemeine Zeitung [de], 21 June 2018. (In German)

48. Chatman, S. Denton woman says Kia Won't Reimburse Her after Car Catches Fire. NBC 5 Dallas-Fort Worth. 2018. Available online: https:/ / www.nbcdfw.com/news/local/Denton-Woman-Says-Kia-Wont-Reimburse-Her-After-Car-Catches-Fire--491 908751.html (accessed on 20 March 2019).

49. Bangkok Post. Porsche catches fire while charging. 2018. Available online: https://www.bangkokpost.com/news/general/1429 518/ porsche-catches-fire-while-charging (accessed on 18 March 2018).

50. EV Century. Lifan 650EV Spontaneously Ignited. GaoGong EV Web. 2018. Available online: http://www.gg-ev.com/asdisp2-6 5b095fb-26641-.html (accessed on 20 March 2019).

51. Bt10m Porsche Up in Flames as Battery Charging Goes Wrong. THE NATION, 16 March 2018. Available online: https://www. nationthailand.com/news/30341102(accessed on 20 March 2019).

52. Gastelu, G. NTSB: Tesla was going $116 \mathrm{mph}$ at time of fatal Florida accident, battery pack reignited twice afterwards. Foxnews, 27 June 2018.

53. Radiotelevisione Svizzera. Rogo A2, batterie in causa. 2018. Available online: https://www.rsi.ch/news/ticino-e-grigioni-einsubria/Rogo-A2-batterie-in-causa-10469564.html (accessed on 10 May 2018).

54. Neue Zurcher Zeitung. Akku ist die mögliche Ursache für Brand bei einem tödlichen Tesla-Unfall im Tessin. 2018. Available online: https:/ / www.nzz.ch/panorama/tesla-unfall-im-tessin-akku-als-moegliche-brandursache-ld.1385766 (accessed on 10 May 2018).

55. Huffman, M. Tesla investigating Model S fire in Los Angeles. Consumeraffairs, 20 June 2018.

56. Beene, R. Tesla car fire examination to be observed by authorities in U.S. Europe.Autonews, 20 June 2018.

57. 2 Federal Agencies Take Closer Look Into Tesla Fire In West Hollywood. Losangeles.cbslocal, 20 June 2018.

58. Lambert, F. Tesla car caught on fire while being investigated for another fire. Electrek, 3 June 2018.

59. Tribune Publishing. Tesla Crash Story. 2019. Available online: https://www.sun-sentinel.com/local/broward/davie/fl-nedavie-tesla-crash-fole-20190225-story.html (accessed on 25 February 2019).

60. Fox News. Tesla Accident in Florida. 2019. Available online: https://www.foxnews.com/auto/driver-killed-in-fiery-teslaaccident-in-florida-after-crashing-into-trees (accessed on 25 February 2019).

61. Burlington Free Press. Tesla Model X burned on frozen Lake Champlain: What happened and what's coming next. 2019. Available online: https: / / www.burlingtonfreepress.com/story/news/local/2019/03/01/tesla-model-x-burned-lake-champlain-whatnext-steps-fire/3026364002/ (accessed on 11 December 2019).

62. cnBeta. Exposure of Shanghai Tesla after Spontaneous Combustion: Audi was Burned to Scrap Metal Next to it-Tesla Electric Vehicle. cnBeta, 22 April 2019. (In Chinese)

63. Caught on camera: Electric SUV plunges into water at Port Moody boat launch. CTV News, 16 May 2019.

64. San Francisco Fire Department Media. Tesla S Fire. 2019. Available online: https://twitter.com/SFFDPIO/status/1124316 (accessed on 16 May 2019).

65. Reuters Staff. Tesla car catches fire in Hong Kong parking lot: Media. Reuters, 3 June 2019.

66. Lambert, F. Tesla vehicle caught on fire while plugged in at Supercharger station. Electrek, 2 June 2019.

67. 4 PDA. Опубликованы подробности возгорания электрокара Tesla в Москве. 2019. Available online: https://4pda.ru/2019/0 8/12/360223/ (accessed on 12 August 2019).

68. Barmash, J. Shocking moment a Tesla bursts into flames while charging. Intercontinental News, 22 November 2019.

69. Canadian Broadcasting Corporation. 2019. Available online: https://www.cbc.ca/news/canada/montreal/electric-car-catchesfire-and-explodes-in-le-bizard-garage-1.5227665 (accessed on 27 July 2019).

70. Dae-sun, H. All Fires in Electric Vehicles in S. Korea This Year Involved Hyundai's Kona Electric. 2019. Available online: http:/ / www.hani.co.kr/arti/english_edition/e_business/912588.html (accessed on 27 July 2019).

71. Hankyoreh. A Next Car Fire. 2019. Available online: http://www.hani.co.kr/arti/english_edition/ (accessed on 14 August 2019).

72. JN. Porsche embate em ponte móvel de Matosinhos e faz dois mortos e quatro feridos. 2019. Available online: https://www.jn.pt/ local/noticias/porto/matosinhos/dois-mortos-e-quatro-feridos-apos-carro-embater-em-ponte-movel-em-leca-10851084.html (accessed on 1 May 2019).

73. CNBC. Electric Porsche Taycan Catches Fire While Parked Overnight in Garage, Company Confirms. 2020. Available online: https:/ / www.cnbc.com/2020/02/18/electric-porsche-taycan-catches-fire-in-garage-company-confirms.html (accessed on 18 February 2020).

74. Tesla. Tesla Vehicle Safety Report. Available online: https:/ /www.tesla.com/VehicleSafetyReport (accessed on 20 March 2019).

75. The Home Office, Road Vehicle Fires Dataset, UK, August 2019. Available online: https://www.gov.uk/government/statisticaldata-sets / fire-statistics-incident-level-datasets (accessed on 20 March 2019).

76. Huang, X.; Nakamura, Y. A review of fundamental combustion phenomena in wire fires. Fire Technol. 2020, 56, 315-360. [CrossRef] 
77. Bisschop, R.; Willstrand, O.; Amon, F.; Rosengren, M. Fire Safety of Lithium-Ion Batteries in Road Vehicles; Safety E Transport Fire Research; RISE Report 2019/50; Research Institutes of Sweden: Borås, Sweden, 2019. [CrossRef]

78. Drysdale, D. An Introduction to Fire Dynamics, 3rd ed.; Wiley: Chichester, UK, 2011.

79. Glassman, I.; Yetter, R.A. Combustion, 4th ed.; Academic Press: New York, NY, USA, 2008.

80. Babrauskas, V. Ignition Handbook; Fire Science Publishers/Society of Fire Protection Engineers: Issaquah, WA, USA, 2003.

81. Larsson, F. Lithium-Ion Battery Safety-Assessment by Abuse Testing. Fluoride Gas Emissions and Fire Propagation; Chalmers University of Technology: Goteborg, Sweden, 2017.

82. Garche, J.; Brandt, K. Li-Battery Safety; Elsevier: Amsterdam, The Netherlands, 2019.

83. Tidblad, A.A. Regulatory outlook on electric vehicle safety. In Proceedings of the 5th International Conference on Fires in Vehicles, Boras, Sweden, 3-4 October 2018.

84. Cabrera Castillo, E. Advances in Battery Technologies for Electric Vehicles; Elsevier: Amsterdam, The Netherlands, 2015.

85. Kong, L.; Li, C.; Jiang, J.; Pecht, M.G. Li-Ion Battery Fire Hazards and Safety Strategies. Energies 2018, 11, 2191. [CrossRef]

86. IEC. Secondary Lithium-Ion Cells for the Propulsion of Electric Road Vehicles-Part 2: Reliability and Abuse Testing; International Electrotechnical Commission: Geneva, Switzerland, 2010.

87. SAEJ2464:2; Electric and Hybrid Electric Vehicle Rechargeable Energy Storages. SAE: Warrendale, PA, USA, 2011.

88. Colella, F. Understanding electric vehicle fires. In Proceedings of the Fire Protection and Safety in Tunnels, Stavanger, Norway, 29 August-1 September 2016.

89. Macneil, D.D.; Lougheed, G.; Lam, C.; Carbonneau, G.; Kroeker, R.; Edwards, D.; Tompkins, J.; Lalime, G. Electric vehicle fire testing. In Proceedings of the 8thEVS-GTR Meeting, Washington, DC, USA, 1-5 June 2015.

90. Brzezinska, D.; Markowski, A. Experimental Investigation and CFD Modelling of the Internal Car Park Environment in Case of Accidental LPG Release. Process Saf. Environ. Prot. 2017, 110, 5-14. [CrossRef]

91. Brzezińska, D. Ventilation System Influence on Hydrogen Explosion Hazards in Industrial Lead-Acid Battery Rooms. Energies 2018, 11, 2086. [CrossRef]

92. Brzezinska, D. LPG Cars in a Car Park Environment-How to Make It Safe. Int. J. Environ. Res. Public Health 2019, 16, 1062. [CrossRef]

93. Brzezinska, D.; Dziubinski, M.; Markowski, A.S. Analyses of LPG Dispersion during Its Accidental Release in Enclosed Car Parks. Ecol. Chem. Eng. S 2017, 24, 249-261. [CrossRef]

94. Lecocq, A.; Bertana, M.; Truchot, B.; Marlair, G. Comparison of the fire consequences of an electric vehicle and an internal combustion engine vehicle. In Proceedings of the International Conference on Fires in Vehicles-FIVE 2012, Chicago, IL, USA, 27-28 September 2012; pp. 183-194.

95. US Department of Transportation. Interim Guidance for Electric and Hybrid Electric Vehicles Equipped with High-Voltage Batteries; US Department of Transportation: Washington, DC, USA, 2014.

96. Wang, Q. Study on fire and fire spread characteristics of lithium ion batteries. In Proceedings of the 2018 China National Symposium on Combustion, Harbin, China, 13-16 September 2018.

97. Łebkowski, A. Electric vehicle fire extinguishing system. Przeglad Elektrotechniczny 2017, 93, 329-332. [CrossRef]

98. Lazarenko, O.; Loik, V.; Shtain, B.; Riegert, D. Research on the Fire Hazards of Cells in Electric Car Batteries. BiTP 2018, $52,108-117$.

99. Verband der Automobilindustrie (VDA). Accident Assistance and Recovery of Vehicles with High-Voltage Systems; Verband der Automobilindustrie eV: Berlin, Germany, 2017; pp. 1-30.

100. Andersson, P.; Wikman, J.; Arvidson, M.; Larsson, F.; Willstrand, O. Safe Introduction of Battery Propulsion at Sea; RISE Research Institutes of Sweden: Goteborg, Sweden, 2017.

101. Schiemann, M.; Bergthorson, J.; Fischer, P.; Scherer, V.; Taroata, D.; Schmid, G. A review on lithium combustion. Appl. Energy 2016, 162, 948-965. [CrossRef]

102. Willstrand, O. To manage Fire Risks Related to Li-Ion Batteries in Vehicles Universitet/Hogskola/Foretag; RISE Research Institutes of Sweden: Geneva, Switzerland, 2019.

103. United Nations Economic and Social Council (UNECE). Agreement concerning the adoption of harmonized technical United Nations regulations for wheeled vehicles, equipment and parts which can be fitted and/or be used on wheeled vehicles and the conditions for reciprocal recognition of approvals granted on the. In Unitied Nations Treaty; United Nations: Geneva, Switzerland, 1958.

104. National Fire Protection Association. Hybrid and Clectric Vehicle Emergency Field Guide; National Fire Protection Association: Quincy, MA, USA, 2014

105. US National Highway Traffic Safety Administration. Interim Guidance for Electric and Hybrid-Electric Vehicles Equipped With High Voltage Batteries (Law Enforcement/Emergency Medical Services/Fire Department; US Department of Transportation: Washington, DC, USA, 2012

106. Curtland, C. Parking Lot EV Chargers. Buildings. 2013. Available online: https://www.buildings.com/article-details/articleid/ 15485/title/parking-lot-ev-chargers/viewall/true (accessed on 19 December 2018).

107. SAE International. Surface Vehicle Recommended Practice J2990, Hybrid and EV First and Second Responder Recommended Practice; Society of Automotive Engineers: Pittsburgh, PA, USA, 2012.

108. EDUCAM. Sectorale Norm EDU 100 V3.0: Veilig Werken aan HEV (Hybrid \& Electric Vehicles). Available online: https:/ /www. educam.be/sites/default/files/inline-files/EDU100V4.0\%20NL_activiteitendomein_garage.pdf (accessed on 20 March 2021). 
109. NIST. FDS and Smokeview Review. 2020. Available online: https://www.nist.gov/services-resources/software/fds-andsmokeview (accessed on 20 March 2021).

110. PD 7974-6:2004; Application of Fire Safety Engineering Principles to the Design of Buildings. Part 6: Human Factors: Life Safety Strategies-Occupant Evacuation, Behaviour and Condition (Sub-System 6). British Standards Institution: London, UK, 2019.

111. McGrattan, K.; Hostikka, S.; Floyd, J.; McDermott, R.; Vanella, M. Fire Dynamics Simulator User's Guide, 6th ed.; National Institute of Standards and Technology: Gaithersburg, MD, USA, 2013.

112. McGrattan, K.B.; McDermott, R.J.; Weinschenk, C.G.; Forney, G.P. Fire Dynamics Simulator, Technical Reference Guide, 6th ed.; National Institute of Standards and Technology: Gaithersburg, MD, USA, 2013.

113. NFPA 204:2021; Standard for Smoke and Heat Venting. National Fire Protection Association: Quincy, MA, USA, 2021. 